\section{JURNAL EKONOMI EFEKTIF}

ISSN : $2622-8882$, E-ISSN : 2622-9935

Jurnal Ekonomi Efektif, Vol. 3, No. 4, Juli 2021

@ Prodi Manajemen Fakultas Ekonomi Universitas

Pamulang

\title{
PENGARUH KOMPETENSI GURU TERHADAP MOTIVASI BELAJAR SISWA PADA SMK DI WILAYAH SERANG BANTEN
}

\author{
Arrum Fathia Sari \\ Sekolah Tinggi Ilmu Ekonomi Dwimulya, Serang, Banten, Indonesia \\ arrumfathiasari@gmail.com
}

Manuskrip: Mei -2021 Ditinjau: Mei -2021; Diterima: Juni-2021; Online: Juli-2021; Diterbitkan: Juli-2021

\begin{abstract}
ABSTRAK
Penelitian ini bertujuan untuk mengetahui pengaruh Kompetensi Guru terhadap Motivasi Belajar Siswa pada SMK di Wilayah Serang, Banten. Metode yang digunakan adalah explanatory research dengan sampel sebanyak 98 responden. Teknik analisis menggunakan analisis statistik dengan pengujian regresi, korelasi, determinasi dan uji hipotesis. Hasil penelitian ini variabel Kompetensi Guru diperoleh nilai rata-rata skor sebesar 3,414 dengan kriteria baik. Variabel Motivasi Belajar Siswa diperoleh nilai rata-rata skor sebesar 3,841 dengan kriteria baik. Kompetensi Guru berpengaruh positif dan signifikan terhadap Motivasi Belajar Siswa dengan nilai persamaan regresi $\mathrm{Y}=9,484+0,847 \mathrm{X}$, dan nilai koefisien korelasi 0,775 atau memiliki tingkat hubungan yang kuat dengan nilai determinasi $60,0 \%$. Uji hipotesis diperoleh signifikansi $0,000<0,05$.
\end{abstract}

Kata Kunci: Kompetensi Guru, Motivasi Belajar Siswa

\begin{abstract}
This study aims to determine the effect of teacher competence on student learning motivation at vocational schools in Serang, Banten. The method used is explanatory research with a sample of 98 respondents. The analysis technique uses statistical analysis with regression, correlation, determination and hypothesis testing. The results of this research variable Teacher Competence obtained an average score of 3,414 with good criteria. Student Learning Motivation Variable obtained an average score of 3.841 with good criteria. Teacher competence has a positive and significant effect on Student Learning Motivation with a regression equation value of $Y=9.484+0.847 X$, and a correlation coefficient value of 0.775 or has a strong relationship with a determination value of $60.0 \%$. Hypothesis testing obtained a significance of $0.000<0.05$.
\end{abstract}

Keywords: Teacher Competence, Student Learning Motivation 


\section{PENDAHULUAN}

\section{A. Latar Belakang}

Pendidikan pada dasarnya merupakan salah satu upaya untuk memberikan pengetahuan wawasan, keterampilan, dan keahlian tertentu pada individu-individu guna menggali dan mengembangkan bakat serta kepribadian mereka. Pendidikan di sekolah dan proses belajar mengajar merupakan kegiatan yang paling pokok, dimana didalamnya terjadi interaksi antara berbagai komponen pembelajaran. Interaksi antara ketiga komponen pembelajaran ini tidak terlepas dari metode, media, serta lingkungan tempat belajar, yang semua ini ikut membantu dalam mencapai tujuan yang telah direncanakan sebelumnya.1Kehidupan di dunia ini rupanya tidak sepi dari kegiatan belajar, guna terbiasa mengambil pelajaran dari seluruh kegiatan, kita bisa mendapatkan banyak keterampilan. Halinilah yang bisa membuat kita lebih unggul modal keterampilan hidup tersebut dan kita akan siap menghadiri perubahan yang begitu cepat dalam dunia ini.2Dengan memiliki keterampilan seseorang haruslah diberi pengetahuan oleh pendidik atau guru yang menjadisalah satu unsur penting dalam kegiatan proses pendidikan. Di pundak pendidik terletak tanggung jawab yang amat besar dalam upaya mengantarkan peserta didik ke arah tujuanpendidikan yang dicita-citakan.3Salah satu yang harus dimiliki seorang guru dalam mencapai tujuan pembelajaran dan pendidikan adalah kompetensi. Kompetensi merupakan perilaku rasional guna mencapai tujuan yang dipersyaratkan sesuai dengan kondisiyang diharapkan. Sebagai suatu profesi, terdapat sejumlah kompetensi yang harus dimiliki seorang guru, yaitu kompetensi pedagogik, kompetensi kepribadian, kompetensi profesional, dan kompetensi sosial kemasyarakatan.4Kompetensi guru tidak berdiri sendiri, tetapi dipengaruhi oleh faktor latar belakang pendidikan, pengalaman mengajar, dan lamanya mengajar. Kompetensi guru dapat dinilai penting sebagai alat seleksi dalam penerimaan calon guru. Juga dapat dijadikan sebagai pedoman dalam rangka pembinaan dan pengembangan tenaga guru.

Selain itu, juga penting dalam hubungannya dengan kegiatan belajar mengajar dan hasil belajar siswa. Guru yang berhasil adalah guru yang memiliki kompetensi dalam menumbuhkan semangat serta motivasi belajar peserta didik, yang pada akhirnya akan mampu meningkatkan kualitas pembelajaran yang dialami oleh peserta didik. Motivasi belajar peserta didik memiliki pengaruh yang kuat terhadap keberhasilan proses maupun hasil belajar peserta didik. Salah satu indikator kualitas pembelajaranadalah adanya motivasi belajar yang besar dan motivasi yang didapatkan baik dari diri sendiri maupun dari guru. Motivasi memiliki pengaruh terhadap perilaku belajar peserta didik, yaitu motivasi mendorong meningkatnya semangat dan ketekunan dalam belajar.

Motivasi belajar memegang peranan yang penting dalam memberi gairah, semangat dan rasa senang dalam belajar sehingga peserta didik yang mempunyai motivasi tinggi mendapatkan energi yang banyak untuk melaksanakan kegiatan belajar yang pada akhirnya akan mampumemperoleh prestasi yang lebih baik. Kompetensi guru sangatlah berpengaruh terhadap peserta didik. Hal tersebut dapat dilihat dari ketertarikan peserta didik dalam proses pembelajaran, misalnya aktif dalam mengajukan pertanyaan, rajin mengumpulkan tugas tepat waktu dan tidak adanya keterlambatan dalam mengikuti pembelajaran di sekolah. Namun informasi yangdiperoleh dari hasil pengamatan yang peneliti lakukan terhadap peserta didik, terlihat dalam kegiatan belajar mengajar sebagian besar peserta didik masih banyak yang kurang serius dalam proses pembelajaran seperti: kurangnya motivasi belajar peserta didikuntuk mata pelajaran tertentu, guru yang tidak memberikan toleransi waktu kepada peserta didik yang terlambat, kurangnya menerapkan motede-metode pembelajaran yang dapat menarik perhatian serta kurangnya motivasi belajar yang diberikanoleh guru kepada peserta didik. Artinya keaktifan yang 
diharapkan oleh guru selama proses pembelajaran tidak sesuai dengan harapan guru. Hal ini menunjukkan bahwa kompetensi guru masih kurang baik dalam hal meningkatkan akademik danbelum mampu sepenuhnya menjadi motivator baik dalam proses pembelajaran maupun di luar pembelajaran. Terkait dengan permasalahan di atas kemudian peneliti ingin mengkaji lebih lanjut hal tersebut dalam sebuah penelitian yang berjudul "Pengaruh Kompetensi Guru Terhadap Motivasi Belajar Siswa Pada SMK Di Wilayah Serang, Banten".

\section{B. Rumusan Masalah}

1. Bagaimana Kompetensi Guru pada SMK di Wilayah Serang, Banten ?.

2. Bagaimana Motivasi Belajar Siswa pada SMK di Wilayah Serang, Banten ?.

3. Adakah pengaruh antara Kompetensi Guru terhadap Motivasi Belajar Siswa pada SMK di Wilayah Serang, Banten?.

\section{Tujuan Penelitian}

1. Untuk mengetahui kondisi Kompetensi Guru pada SMK di Wilayah Serang, Banten.

2. Untuk mengetahui kondisi Motivasi Belajar Siswa pada SMK di Wilayah Serang, Banten.

3. Untuk mengetahui pengaruh Kompetensi Guru terhadap Motivasi Belajar Siswa pada SMK di Wilayah Serang, Banten.

\section{TINJAUAN PUSTAKA}

\section{Kompetensi Guru}

Kompetensi guru merupakan skor yang diperoleh dari jawaban tentang kemampuan seorang guru dalam melaksanakan kewajiban-kewajiban secara bertanggungjawab dan layak.7Skortersebut diperoleh berdasarkan kompetensi profesional dengan indikator: 1) kemampuan merencanakan program belajar mengajar, 2) menguasai bahan pelajaran, 3) melaksanakan atau mengelola proses belajar mengajar dengan kreatif dan inovatif, 4) menilai kemajuan proses belajar

\section{Motivasi Belajar Siswa}

Motivasi belajar merupakan skor yang diperoleh dari jawaban tentang daya penggerak/pendorong untuk meningkatkan proses belajar peserta didik yang biasa berasal dari dalam diri dan juga dari luar. Skor tersebut diperoleh berdasarkan aspek intrinsik dengan indikator: 1) keinginan untuk belajar, 2) menyelesaikan tugas, 3) senang mengikuti pelajaran,4) mengembangkan bakat dan pengetahuan. Sedangkan aspek ekstrinsik dengan indikator: 1) mendapat perhatian, 2) mendapat pujian, 3) mendapatkan hadiah atau penghargaan, 4) taat peraturan atau tertib sekolah, 5) guru dan orang tua menjadi suri tauladan, 6) pengaruh teman-teman, 7) proses belajar menagajar yang menarik

\section{METODE PENELITIAN}

\section{Populasi}

Populasi dalam penelitian ini berjumlah 98 responden SMK di Wilayah Serang, Banten

2. Sampel

Teknik pengambilan sampling dalam penelitian ini adalah sampel jenuh, dimana semua anggota populasi dijadikan sebagai sampel. Dengan demikian sampel dalam penelitian ini sampel yang digunakan berjumlah 98 responden. 


\section{Jenis Penelitian}

Jenis penelitian yang dipakai adalah asosiatif, dimana tujuannya adalah untuk mengetahui atau mencari keterhubungan antara variabel independen terhadap variabel dependennya

\section{Metode Analisis Data}

Dalam menganalisis data digunakan uji validitas, uji reliabilitas, analisis regresi linier sederhana, analisis koefisien korelasi, analisis koefisien determinasi dan pengujian hipotesis.

\section{HASIL PENELITIAN}

\section{Analisis Deskriptif}

Pada pengujian ini digunakan untuk mengetahui skor minimum dan maksimum skor tertinggi, ratting score dan standar deviasi dari masing-masing variabel. Adapun hasilnya sebagai berikut:

Tabel 1. Hasil Analisis Descriptive Statistics

Descriptive Statistics

\begin{tabular}{lr|r|r|r|r} 
& N & Minimum & Maximum & Mean & Std. Deviation \\
\hline Kompetensi Guru (X) & 98 & 28 & 44 & 34.13 & 3.887 \\
\hline Motivasi Belajar Siswa (Y) & 98 & 29 & 49 & 38.41 & 4.252 \\
\hline Valid N (listwise) & 98 & & & & \\
\hline
\end{tabular}

Kompetensi Guru diperoleh varians minimum sebesar 28 dan varians maximum 44 dengan ratting score sebesar 3,414 dengan standar deviasi 3,887. Skor ini termasuk pada rentang sakala 3,40-4,19 dengan kriteria baik atau setuju.

Motivasi Belajar Siswa diperoleh varians minimum sebesar 29 dan varians maximum 49 dengan ratting score sebesar 3,841 dengan standar deviasi 4,252. Skor ini termasuk pada rentang sakala 3,40-4,19 dengan kriteria baik atau setuju.

\section{Analisis Kuantitatif}

Pada analisis ini dimaksudkan untuk mengetahui pengaruh variabel independen terhadap variabel dependen. Adapun hasil pengujian sebagai berikut:

\section{a. Analisis Regresi Linier Sederhana}

Uji regresi ini dimaksudkan untuk mengetahui perubahan variabel dependen jika variabel independen mengalami perubahan. Adapun hasil pengujiannya sebagai berikut:

Tabel 2. Hasil Pengujian Regresi Linier Sederhana Coefficients $^{\mathbf{a}}$

\begin{tabular}{|c|c|c|c|c|c|}
\hline \multirow[b]{3}{*}{ Model } & \multicolumn{2}{|c|}{ Coemcients } & \multirow{3}{*}{$\begin{array}{l}\text { Standardized } \\
\text { Coefficients }\end{array}$} & \multirow[b]{3}{*}{$\mathrm{t}$} & \multirow[b]{3}{*}{ Sig. } \\
\hline & \multicolumn{2}{|c|}{$\begin{array}{l}\text { Unstandardized } \\
\text { Coefficients }\end{array}$} & & & \\
\hline & $\mathrm{B}$ & Std. Error & & & \\
\hline 1 (Constant) & 9.484 & 2.426 & & 3.910 & .000 \\
\hline Kompetensi Guru (X) & .847 & .071 & .775 & 12.000 & .000 \\
\hline
\end{tabular}

Berdasarkan hasil pengujian pada tabel di atas, diperoleh persamaan regresi $\mathrm{Y}$ $=9,484+0,847 X$. Dari persamaan tersebut dijelaskan sebagai berikut:

1) Konstanta sebesar 9,484 diartikan jika Kompetensi Guru tidak ada, maka telah terdapat nilai Motivasi Belajar Siswa sebesar 9,484 point.

2) Koefisien regresi Kompetensi Guru sebesar 0,847, angka ini positif artinya setiap ada peningkatan Kompetensi Guru sebesar 0,847 point maka Motivasi Belajar Siswa juga akan mengalami peningkatan sebesar 0,847 point. 


\section{b. Analisis Koefisien Korelasi}

Analisis koefisien korelasi dimaksudkan untuk mengetahui tingkat kekuatan hubungan dari variabel independen terhadap variabel dependen. Adapun hasil pengujian sebagai berikut:

Tabel 3. Hasil Pengujian Koefisien Korelasi Kompetensi Guru Terhadap Motivasi

Belajar Siswa.

\begin{tabular}{llr|r} 
& \multicolumn{1}{c}{ Correlations $^{\mathbf{b}}$} & \multicolumn{1}{c}{$\begin{array}{c}\text { Kompetensi } \\
\text { Guru (X1) }\end{array}$} & \multicolumn{2}{c}{$\begin{array}{c}\text { Motivasi Belajar } \\
\text { Siswa (Y) }\end{array}$} \\
\hline Kompetensi Guru (X) & Pearson Correlation & 1 & $.775^{* *}$ \\
\cline { 2 - 4 } & Sig. (2-tailed) & & .000 \\
\hline $\begin{array}{l}\text { Motivasi Belajar Siswa } \\
\text { (Y) }\end{array}$ & Pearson Correlation & $.775^{* *}$ & 1 \\
\cline { 2 - 4 } & Sig. (2-tailed) & .000 & \\
\hline
\end{tabular}

Berdasarkan hasil pengujian diperoleh nilai korelasi sebesar 0,775 artinya Kompetensi Guru memiliki hubungan yang kuat terhadap Motivasi Belajar Siswa.

\section{c. Analisis Koefisien Determinasi}

Analisis koefisien determinasi dimaksudkan untuk mengetahui besarnya persentase pengaruh dari variabel independen terhadap variabel dependen. Adapun hasil pengujian sebagai berikut:

Tabel 4. Hasil Pengujian Koefisien Determinasi Kompetensi Guru Terhadap Motivasi Belajar Siswa.

\begin{tabular}{|c|c|c|c|c|}
\hline \multicolumn{5}{|c|}{ Model Summary } \\
\hline Model & $\mathrm{R}$ & R Square & $\begin{array}{l}\text { Adjusted R } \\
\text { Square }\end{array}$ & $\begin{array}{l}\text { Std. Error of the } \\
\text { Estimate }\end{array}$ \\
\hline 1 & $.775^{\mathrm{a}}$ & .600 & .596 & 2.703 \\
\hline
\end{tabular}

Berdasarkan hasil pengujian diperoleh nilai determinasi sebesar 0,600 artinya Kompetensi Guru memiliki kontribusi pengaruh sebesar 60,0\% terhadap Motivasi Belajar Siswa, sedangkan sisanya sebesar 40,0\% dipengaruhi oleh faktor lain yang tidak dilakukan penelitian.

\section{d. Uji Hipotesis}

Pengujian hipotesis dengan uji t digunakan untuk mengetahui hipotesis mana yang diterima.

Rumusan hipotesis: Terdapat pengaruh yang signifikan Kompetensi Guru terhadap Motivasi Belajar Siswa.

Tabel 5. Hasil Uji Hipotesis Kompetensi Guru Terhadap Motivasi Belajar Siswa.

\begin{tabular}{lr|r|r|r|r} 
& \multicolumn{2}{c}{$\begin{array}{c}\text { Coefficients } \\
\text { Unstandardized } \\
\text { Coefficients }\end{array}$} & $\begin{array}{c}\text { Standardized } \\
\text { Coefficients }\end{array}$ & & \\
Model & $\mathrm{B}$ & Std. Error & \multicolumn{1}{c|}{ Beta } & \multicolumn{1}{c|}{$\mathrm{t}$} & \multicolumn{1}{c}{ Sig. } \\
\hline 1 & 9.484 & 2.426 & & 3.910 & .000 \\
\hline (Constant) & .847 & .071 & .775 & 12.000 & .000 \\
\hline
\end{tabular}

Berdasarkan hasil pengujian pada tabel di atas, diperoleh nilai t hitung $>\mathrm{t}$ tabel atau $(12,000>1,985)$, dengan demikian hipotesis yang diajukan bahwa terdapat pengaruh yang signifikan atara Kompetensi Guru terhadap Motivasi Belajar Siswa diterima. 


\section{Pembahasan Hasil Penelitian}

\section{Kondisi Jawaban Responden Variabel Kompetensi Guru}

Berdasarkan jawaban responden, variabel Kompetensi Guru diperoleh ratting score sebesar 3,414 berada di rentang skala 3,40 - 4,19 dengan kriteria baik atau setuju.

\section{Kondisi Jawaban Responden Variabel Motivasi Belajar Siswa}

Berdasarkan jawaban responden, variabel Motivasi Belajar Siswa diperoleh ratting score sebesar 3,841 berada di rentang skala 3,40 - 4,19 dengan kriteria baik atau setuju.

\section{Pengaruh Kompetensi Guru Terhadap Motivasi Belajar Siswa}

Kompetensi Guru berpengaruh signifikan terhadap Motivasi Belajar Siswa dengan persamaan regresi $\mathrm{Y}=9,484+0,847 \mathrm{X}$, nilai korelasi sebesar 0,775 atau memiliki hubungan yang kuat dengan kontribusi pengaruh sebesar $60,0 \%$. Pengujian hipotesis diperoleh nilai $\mathrm{t}$ hitung $>\mathrm{t}$ tabel atau $(12,000>1,985)$. Dengan demikian hipotesis yang diajukan bahwa terdapat berpengaruh signifikan antara Kompetensi Guru terhadap Motivasi Belajar Siswa diterima.

\section{KESIMPULAN DAN SARAN}

\section{Kesimpulan}

a. Variabel Kompetensi Guru diperoleh ratting score sebesar 3,414 berada di rentang skala 3,40 - 4,19 dengan kriteria baik atau setuju.

b. Variabel Motivasi Belajar Siswa diperoleh ratting score sebesar 3,841 berada di rentang skala 3,40-4,19 dengan kriteria baik atau setuju.

c. Kompetensi Guru berpengaruh signifikan terhadap Motivasi Belajar Siswa dengan persamaan regresi $\mathrm{Y}=9,484+0,847 \mathrm{X}$, nilai korelasi sebesar 0,775 atau kuat dan kontribusi pengaruh sebesar $60,0 \%$ sedangkan sisanya sebesar $40,0 \%$ dipengaruhi faktor lain. Uji hipotesis diperoleh nilai $t$ hitung $>t$ tabel atau $(12,000>1,985)$.

\section{Saran}

a. Sekolah harus berupaya mengirimkan tenaga pengajarnya ke pelatihan dan seminarseminar baik terkait pendidikan maupun pengembangan diri agar memiliki kompetensi yang diharapkan.

b. Sekolah harus terus mendorong siswa agar tetap memiliki semangat belajar yang tinggi agar berprestasi dengan lebih baik lagi

\section{DAFTAR PUSTAKA}

Abdullah, M (2014) Manajemen dan Evaluasi Motivasi Belajar Siswa, Yogyakarta: Penerbit Aswaja Pressindo.

Algifari. (2015). "Analisis Regresi untuk Bisnis dan Ekonomi”. Yogyakarta: BPFE.

Arikunto, Suharsimi (2014). "Prosedur Penelitian Suatu Pendekatan Praktek”. Wilayah Serang, Banten: Rineka Cipta.

Bejo Siswanto (2013) Manajemen Tenaga Kerja Rancangan dalam Pendayagunaan dan Pengembangan Unsur Tenaga Kerja”, Bandung: Sinar Baru.

Dessler, G. (2006.) Manajemen Sumber Daya Manusia (Jilid II). Wilayah Serang, Banten: Indeks.

Dewi, R. V. K., Sunarsi, D., \& Akbar, I. R. (2020). Dampak Penggunaan Teknologi Informasi dan Komunikasi Terhadap Minat Belajar Siswa di SMK Ganesa Satria Depok. Jurnal Ilmiah Wahana Pendidikan, 6(4), 1001-1007. 
Edi Sutrisno (2016). Manajemen Sumber Daya Manusia. Wilayah Serang, Banten: Prenadamedia Group.

George Terry R \& Rue, Leslie W. Rue (2016) Dasar-Dasar Manajemen, Wilayah Serang, Banten Bumi Aksara.

Gerry Dessler (2016) Human Resources Management, Prenticehall, London: International Inc.

Guruh, M. (2018). Pengaruh Kompetensi Terhadap Kinerja Guru Pada SMK Kartika X-2. JENIUS (Jurnal Ilmiah Manajemen Sumber Daya Manusia), 2(1).

Handoko (2016) Manajemen Personalia dan Sumberdaya Manusia. Yogyakarta: BPFE.

Hasibuan, Malayu S.P. (2016). Manajemen Sumber Daya Manusia. Edisi Revisi. Wilayah Serang, Banten: PT Bumi Aksara.

Imam Ghozali (2017). "Aplikasi Analisis Multivariate Dengan Program SPSS”. Edisi Kelima. Semarang: Badan Penerbit Undip.

Istijanto (2014) “Riset Sumber Daya Manusia”. Wilayah Serang, Banten: PT. Gramedia Pustaka

Kharis, Ismu Fadli (2011). "Studi Mengenai Impulse Buying dalam Penjualan Online”. Semarang : Skripsi Universitas Diponegoro

Khoiri, A., Komariah, N., Utami, R. T., Paramarta, V., \& Sunarsi, D. (2021, February). 4Cs Analysis of 21st Century Skills-Based School Areas. In Journal of Physics: Conference Series (Vol. 1764, No. 1, p. 012142). IOP Publishing.

Mangkunegara, Prabu Anwar. (2016). Evaluasi Kinerja SDM. Cetakan ke tujuh, PT Refika Aditama: Bandung.

Mogi, A. (2018). Pengaruh Kompetensi Guru, Motivasi Guru Dan Lingkungan Sekolah Terhadap Hasil Belajar Siswa Sma Tunas Indonesia Bintaro. JENIUS (Jurnal Ilmiah Manajemen Sumber Daya Manusia), 1(2).

Rozi, A., Khoiri, A., Farida, R. D. M., Sunarsi, D., \& Iswadi, U. (2021, February). The fullness of Higher Order Thinking Skills (HOTs) in Applied Science Textbooks of Vocational Schools. In Journal of Physics: Conference Series (Vol. 1764, No. 1, p. 012143). IOP Publishing.

Sampurnaningsih, S. R., Andriani, J., Zainudin, Z. A. B. A., \& Sunarsi, D. (2020). The Analysis of Entrepreneurship Character and Entrepreneurship Intention among Students. PalArch's Journal of Archaeology of Egypt/Egyptology, 17(6), 8290-8303. Santoso, Singgih (2015). "Menguasai Statistik Multivariat”. Wilayah Serang, Banten: PT Elex Media Komputindo.

Sedarmayanti (2016) Manajemen Sumber Daya Manusia, Reformasi Birokrasi dan Manajemen Karyawan Negeri Sipil, Cetakan Kelima, Bandung: PT Refika Aditama.

Sudiarto, S. (2018). Membangun Motivasi Kerja Guru Dalam Menyiapkan Sumber Daya Manusia Indonesia Yang Berkualitas (Analisis Teori Motivasi Abraham Maslow Di SMK Negeri 57 Jakarta). JENIUS (Jurnal Ilmiah Manajemen Sumber Daya Manusia), 1(3).

Sudjana (2014) "Metode Statistika”, Bandung: Tarsido.

Sugiyono (2017), "Metode Penelitian Administrasi : dilengkapi dengan Metode $R \&$ D”. Bandung: Alfabeta.

Veithzal Rivai (2015) Manajemen Sumber Daya Manusia Untuk Perusahaan, Wilayah Serang, Banten: Raja Grafindo Persada.

Wibowo (2015) Manajemen Kinerja, Wilayah Serang, Banten: PT. Raja Grafindo Persada. 